\title{
A NEW INTERVENTION IN THE NATIONAL IMAGINARY: \\ THE PORTRAYAL OF THE SOUTHWEST IN THE NOVELS OF PAUL AUSTER
}

\author{
Slawomir Studniarz \\ University of Warmia and Mazury \\ slawomirstudniarz@wp.pl
}

Received 27 July 2019

Accepted 8 January 2020

KEYWORDS: the myth of the West; American Dream; wilderness; the mystique of the Southwest; alternative history; trauma; space

PALABRAS CLAVE: el mito del Oeste; el sueño americano; naturaleza virgen; la mística del Suroeste; historia alternativa; trauma; espacio

\begin{abstract}
The article focuses on two novels by Paul Auster, The Book of Illusions (2002), Travels in the Scriptorium (2006), in which the Southwest emerges as a mythical territory, providing a rich ground in which the American grand narratives can be explored and revised. It is the contention of the article that the choice of this particular locale affords an excellent opportunity for a critical engagement with the national imaginary, the powerful myths shaping the American imagination. Travels in the Scriptorium reinvents the Southwest as the bloody arena on which the American imperialist mission is reenacted. In the novel, the Alien Territories, representing the American Southwest in the historical expansion of the United States, figure as a site of vicious struggle and ruthless conquest. By contrast, The Book of Illusions, presents the Southwest, specifically New Mexico, as the last mainstay of the American Dream. The creation of the Blue Stone Ranch in the "wilderness" of New Mexico and its transformation encapsulate the history of the American nation in its essential stages. But more importantly, the Southwest is envisioned as a region invested with a restorative, almost sacred quality. The Book of Mlusion is the story of trauma. And the recovery from trauma is a process that either originates or takes place in New Mexico.
\end{abstract}

\section{RESUMEN}

Este artículo se centra en dos novelas de Paul Auster, The Book of Illusions (2002) y Travels in the Scriptorium (2006) en las cuales el 
Sudoeste emerge como un territorio mítico que proporciona un espacio para la exploración y revisión de las grandes narrativas americanas. El propósito es señalar la elección de esta localización en particular como una oportunidad excelente para desarrollar un compromiso crítico con el imaginario nacional, conformado por los sólidos mitos y representaciones que configuran la imaginación americana. Travels in the Scriptorium redefine el Sudoeste como el terreno sangriento en el que se recrea la misión colonialista americana. En la novela, los Territorios Foráneos, que representan el sudoeste americano dentro de la expansión histórica de los Estados Unidos figuran como un lugar de lucha y conquista violentas. Por el contrario, The Book of Ilusions presenta el Sudoeste, Nuevo México específicamente, como el último pilar del sueño americano. La creación del rancho Blue Stone en las tierras salvajes de Nuevo México y su transformación comprenden la historia de la nación americana en sus etapas constitutivas. De forma significativa, el Sudoeste se concibe como una región con rasgos revitalizadores, casi sagrados. Así, The Book of Illusions es la historia del trauma cuyo proceso de recuperación se origina y tiene lugar en Nuevo México.

Since the title of the article suggests its concern with narrative spatiality, it might do well to offer some remarks on the theory of literary space before proceeding to the discussion of the specific treatment of the Southwest in Travels in the Scriptorium and The Book of Mlusions, the two examined novels of Paul Auster. Gabriel Zoran, in his 1984 article "Towards a Theory of Space in Narrative," makes a point that still holds true after 30 years, stating that "research in general on the subject [of literary space] is quite diffuse, and there are few assumptions that have become generally accepted" (310). He draws attention to the basic difficulty in understanding the nature of space in fiction, which is fundamentally different from space in ordinary human experience, which, as Zoran points out, "has to do with concepts such as volume, extension, and threedimensionality, and all these are unrelated to the concept of the spatial pattern" in narratives, because this pattern "is a kind of abstract organization" and it "does not stand in any kind of correlation with the space of the world" (312). He rightly states that what is meant by literary space is "actually a combination of various kinds and levels of reconstruction" (Zoran 313).

Unfortunately, in the following decades research on narrative spatiality did not show any considerable advance, and the privileging of time in narrative poetics was rarely challenged. Susan Stanford 
Friedman in her 2005 essay "Spatial Poetics and Arundhati Roy's The God of Small Things" produces an impressive list of philosophers and literary scholars who have either failed to address the issue of literary space, thus perpetuating the privileging of time over space in narrative, or opted for the compensatory emphasis on space in studies of fiction (192-193). Notwithstanding this, Friedman's essay does not really go toward filling the gap in the research on narrative space, for the term "spatial poetics" is rather loosely applied there and as such the text does not contribute much to the studies of spatiality in fiction.

The classificatory approach to literary space seems to prevail in contemporary narrative poetics, accompanied by the proliferation of terminology, as evidenced for instance by the entry "Space" in The Living Handbook of Narratology, in which Marie-Laure Ryan distinguishes as many as five different levels in reconstructing the fictional space: spatial frames, setting, story space, narrative (or story) world, and narrative universe. When it comes to understanding the nature and the function of narrative spatiality, judging by the prevalence of Jurij Lotman's terminology and the generative force of his propositions, it is quite safe to assume that the truly seminal work in this field was Lotman's The Structure of The Artistic Text. Written in the early 1970s, the study for many years has remained the touchstone for any serious explorations of space in literature, which is demonstrated for instance by Katharina Hansen Löve's wide-ranging The Evolution of Space in Russian Literature published in 1994. In the sections "The Problem of Artistic Space" and "The Problem of Plot" Lotman made several important and influential claims, beginning with the crucial observation that "beyond the description of the things and objects which make up the environment of a text's personae, there arises a system of spatial relations, the structure of the topos" (231). In addition to "serving as the principle of organization and disposition of the personae within the artistic continuum," Lotman argues, "the structure of the topos emerges as the language for expressing other, non-spatial relations in the text," which determines "the special modeling role of space within a text" (232). Spatial arrangements, then, can be readily invested with a wide range of meanings: social, cultural, ideological or ethical.

Space has always figured largely in the fiction of Paul Auster. The New York Trilogy, the work that has launched his literary career, exploits the urban landscape of New York, turning its topography 
into a blank page on which the movements of one of the characters trace a verbal message. The novels Moon Palace (1989) and $M r$. Vertigo (1994) were Auster's first forays into the American West. With The Book of Mlusions (2002), his fictional universe has widened to incorporate the Southwest, which is evoked also in the subsequent novel Travels in the Scriptorium, published in 2006. In these two texts the region acquires a truly mythical stature, providing a rich imaginative ground in which the American grand narratives can be explored and revised, for it is the contention of the present article that the choice of this particular locale affords an excellent opportunity for a critical engagement with the powerful myths shaping the American imagination, with the national imaginary.

The term "national imaginary" in the title of the article is employed here in the sense that Pauline Strong in her recent study American Indians and the American Imaginary provides, as deriving from the seminal works of Benedict Anderson and Annette Hamilton. As she puts it,

All contemporary treatments of nationalism have been profoundly influenced by Benedict Anderson's (1983) concept of the "imagined community." Annette Hamilton (1990) has built on Anderson's concept in defining "national imaginary" as the process through which collective selves and others emerge "not from the realm of concrete everyday experience but in the circulation of collectively held images." (17)

Among the chief constituents of the national imaginary that have recently surged to prominence, Kelly Denton-Borhaug posits "the necessary sacrifice of war," which she explains as "glorifying the practices of war as the ultimate form of citizenship, the most prized way of belonging to the nation" (32). But from the historical perspective, it appears that the American national identity has been largely constructed around the culturally transmitted and perpetuated images of the West, coalescing in the powerful myth of the conquest of the West. In the case of the discussed novels this mythical territory is incarnated in the Southwest, distinguished from the West at large by its deep and complex past, the "visibility" of its history, and the mosaic-like juxtaposition of ethnic groups and nations. The American Southwest has been variously defined even in geographical terms, and its borders are rather fluid. David Dunaway 
A New Intervention in the National Imaginary:

The Portrayal of the Southwest in the Novels of Paul Auster

and Sara Spurgeon, the editors of the volume Writing the Southwest, offer the following basic definition of the region:

By "Southwest" we refer primarily to Arizona, Colorado, and New Mexico, states that share the Colorado Plateau, the upper Rio Grande valley, and the arid land surrounding it. This region is bounded, in literary historian Lawrence Powell's terms, by "the land east of the Rio Colorado, South of the Mesa Verde, West of the Pecos, and North of the border." (xxii)

But they caution that its range "could be expanded in all directions: North to Utah, South to Mexico, West to California, and East to Texas and Oklahoma" (xxiii). The same authors also point out the unique characteristics of the region: its "juxtaposition of ancient and modern, of traditional cultures which have struggled to maintain much of their histories and lore into the modern technological age," and "the blending, intertwining, and cross-pollinating, based in a diversity found in few other places" (xxiii).

Travels in the Scriptorium and The Book of Illusions offer complex and in many ways contrastive visions of the Southwest, which will be examined in the present article. I have first touched, albeit briefly, on the significance of the Southwest in my article "The American Waste: A New Take on the Conquest of the West in Paul Auster's Novel Travels in the Scriptorium." I have argued there that the novel critically reappraises two foundational myths of the American nation -"the westward expansion as the cradle of the American character and the proving ground of democracy, promoted especially by Turner, and the original 'errand into the wilderness,' with Manifest Destiny as its later incarnation justifying the imperialist mission" (Studniarz 101). However, in the earlier article the question of the mythical status of the Southwest is only secondary, since the exploration of the fictional territory is subordinated there to the main aim, which is the examination of the alternative history of the USA. Consequently, my analysis there deals with the rewriting of the specific moment in American history and, augmented slightly with the ecocritical perspective, falls almost entirely within the theoretical framework of counterfactual history, so conspicuously present in much twentieth- and twenty-first century literature, both fiction and non-fiction.

In Travels in the Scriptorium the American Southwest has been reinvented as the Alien Territories, which in the inserted story 
becomes a site of brutal contest between the imperialistic Confederation and the aboriginal tribes of the so-called Primitives, the derogatory designation of the native inhabitants adopted by the official discourse to affirm the supremacy of the Confederation culture. The Confederation has inexorably pushed the aboriginal inhabitants to the Alien Territories, which turn out to be their last stay against the onslaught of the imperialist power. The Minister of Internal Affairs, Joubert, summarizes aptly the policy of the Confederation with regard to the Primitives: "We slaughtered them and enslaved them and then we herded them together in the parched and barren territories beyond the western provinces" (Auster Travels 73). The vast desert land referred to by the fictional character unmistakably suggests the American Southwest, which at some point in the narrative is rendered in its signature features: "Emptiness all around, a ferocious blue sky overhead, pounding light, and then, when the sun goes down, a chill to freeze the marrow in your bones" (Auster Travels 91). The contested territories appear indeed as the spitting image of Utah, Arizona, Nevada, and New Mexico, and the identity of the Alien Territories with the American Southwest is clinched by the description of "a barren plain in the north-central region of the Territories, a stretch of country similar to the sail flats in Utah" (Auster Travels 119).

The embedded narrative read by Mr. Blank, the protagonist of the novel, is ostensibly a report written by one Sigmund Graf, a public servant employed at the Bureau of Internal Affairs. He writes his report in prison in Ultima, "the westernmost tip of the Confederation, the place that stands at the edge of the known world" (Auster 14). In the place of his confinement he can feel "the dry distances," the vast expanses of inhospitable desolate country that had been his home for several months:

Each time the wind blows from the west, I can smell the sage and juniper bushes, the minima of those dry distances. I lived out there on my own for close to four months, wandering freely from one place to another, sleeping outdoors in all kinds of weather, and to return from the openness of that country to the narrow confines of this room has not been easy for me. (Auster Travels 13)

Graf has been sent into the Alien Territories on a secret mission, whose avowed purpose was to investigate the operations of a potential subversive, Ernesto Land, who according to Minister 
Joubert, was "stirring up discontent among the Primitives, preparing to lead them in an insurrection against the western provinces" (Auster Travels 72). Graf dismisses the suggestion, stating that "An uprising is impossible," since "Military action would require unity among the Primitives, and that has never happened and never will" (Auster Travels 72). Indeed, the idea of the hatched insurrection is just a thinly veiled pretext for invading the Alien Territories and eliminating the natives. This ruthless move is dictated by the logic of imperialist expansion, for as Mr. Blank observes,

the Confederation is a fragile, newly formed state composed of previously independent colonies and principalities, and in order to hold this tenuous union together, what better way to unite the people than to invent a common enemy and start a war? (Auster Travels 88)

In his essay on Auster's novels Jesús Ángel González relevantly points out that

The connection with American myths and the critique of American past and present history seems to be quite straightforward: the creation of a common enemy as an excuse for a 'phony' war can be related to real nineteenth-century wars with the Native Americans, Mexico or Spain, but also to the contemporary Iraqi or Afghan wars. (“Alternative Americas" 29)

In Auster's novel, Graf's ride into the wilderness leads to the discovery of a grisly slaughter perpetrated on the Gangi people, one of the tribes:

The moment he enters, he's greeted by the overpowering stench of death, the sickening smell of decomposing bodies, and there, in the dim light of the hogan, he sees a dozen slaughtered Gangi-men, women, and children-all of them shot down in cold blood. (Auster Travels 91)

The consequences of Graf's discovery remain a mystery, for the typescript ends abruptly. Much to his surprise, Mr. Blank learns that the seeming report is in fact a fictional work, a novel with the missing final pages. The authorship of the narrative is ostensibly attributed to John Trause, a fictional figure introduced in Auster's 2003 novel Oracle Night. The completion of the story is now delegated to Mr. Blank, who takes up the task eagerly: "Back to the beginning. 
Part two, that is. Back to the beginning of part two, when Graf slips across the border and enters the Alien Territories. Forget the massacre of the Gangi" (Auster 118). Mr. Blank significantly rewrites Graf's venture into the wilderness. In the recast scenario, the agent of the Confederation stumbles on a pile of the butchered people, but with a difference -all of the victims are white and uniformed men. Graf spots Land among them, which he takes as proof that Land and his party had been brutally murdered by the Primitives. The fact that he makes a grave misjudgment gives rise to the most poignant ironic twist in the revised version of the events. His indisputable "eyewitness" account lends the much-needed semblance of legitimacy to the ensuing massacre of the natives and the conquest of their territory.

As David Murdoch observes in The American West: The Invention of a Myth, the myth of the conquest of the West "presents the Indian as alien, implacable and irredeemable, an aspect (perhaps the most fearsome aspect) of the untamed land to be conquered by the march of progress" (Murdoch 9). The mastery and exploitation of nature was inscribed in the very process of creating a civilized state on the pristine continent. As John Opie and Norbert Elliot argue in "Tracking the Elusive Jeremiad: The Rhetorical Character of American Environmental Discourse," American history could be perceived as "a narrative of the gradual conquest of the American wilderness, a demonstration of civilization's growing mastery of natural resources, a manifestation of built environments that celebrate their independence from nature" (18). For most Americans, as Murdoch observes, the land was "savage and cruel, like its aboriginal inhabitants the Indians -but it was potentially bountiful": "it offered the opportunity of independence to whoever could seize and use it" (2). The ensuing conquest of the Western wilderness had been at a certain point translated into a powerful national myth, the myth of the West. Murdoch claims that it is easy to demonstrate that "the myth of the West arose out of a crisis which exposed a contradiction at the heart of America's self-image," the crisis "in the minds of many Americans, who saw a frightening conflict between how they conceived their country and what it had become" (20). Auster's novel, thus, casts the westward expansion in a new light, presenting it as a brutal invasion and ruthless conquest. It also exposes the costs at which "the West was won," for the price includes the destruction of the wilderness, and the displacement and eradication of Native Americans. 
While Travels in the Scriptorium enlists the Southwest as the bloody arena on which the American imperialist mission is reenacted, The Book of Illusions, the chronologically earlier novel, presents New Mexico as the last mainstay of the American Dream and the region invested with a restorative, almost sacred quality. However, González argues in "Western Images in Paul Auster's Work: from Moon Palace to Later Fiction" that "the emphasis now seems to be placed on the connection between the American West and transient images (in this case the moving images of films) and the difficulties of artistic representation" ("Western Images"13). New Mexico, in many important ways the heartland of the Southwest, provides a safe haven to the novel's elusive central character, Hector Mann, a one-time comedian starring in silent movies, who in 1929 suddenly decides to end his promising career. Following this renunciatory gesture, after a long and excruciating ordeal, he finally settles near Tierra del Sueño, Land of Dream. The ranch that he creates from scratch becomes simultaneously his refuge and a place for secretly pursuing his artistic passion, making movies. He builds there a private studio, unknown to the world at large, which becomes a virtual alternative to the official center of film-making industry, Hollywood. New Mexico affects also the protagonist of the novel, David Zimmer, who as a result of his visit to Hector Mann's ranch in 1988, even though exceedingly brief, experiences a renewal, a recuperation from the trauma incurred by the loss of his entire family in a plane crash.

Zimmer is the author of the study The Silent World of Hector Mann, which was published in 1988, and he begins his narration eleven years later, in 1999, on the eve of a new millennium. The writing of the book temporarily alleviated his trauma. It "had been born of a great sorrow" (Auster Illusions 5) and writing turned out to have an anesthetic effect on him. He called it "an odd form of medicine," which dulled "the pain inside [him]" (Auster Mlusions 5). After the catastrophe, in the ensuing period of mourning he had "lived in a blur of alcoholic grief and self-pity," and from this sordid and pitiful condition he was lifted by the accidental discovery of Hector Mann's silent comic films. A clip from one of Hector's old films shown on television made him laugh, and he realized that despite his pursuit of self-destruction some part of his self did not want to die. Once the book on Hector's films is completed, Zimmer accepts a new task, translating Chateaubriand's memoirs. The translation work, described by Zimmer as burying himself in the massive chronicle of a 
life that had nothing to do with his life, offers him a means to escape the reality of his own life, a relief from the trauma.

Vermont, Zimmer's place of residence and the site closely associated with his personal tragedy and the sense of a devastating loss, and the curative, revitalizing New Mexico, are the two poles of the fictional world of the novel. The Southwest first enters Zimmer's life by means of a letter with the stamp postmarked Albuquerque, New Mexico. The address, "Blue Stone Ranch; Tierra del Sueňo," sounds so exotic that Zimmer at first does not believe the place is real. Its designation as "Land of Dream" reveals the mythic status of the Southwest in the novel, its association with the American Dream. It points to the original vision of the New World, which as Nick Carraway muses at the end of The Great Gatsby, was "the last and greatest of all human dreams," and "for a transitory enchanted moment man must have held his breath in the presence of this continent [...] face to face for the last time in history with something commensurate to his capacity for wonder" (Fitzgerald 180).

The letter informs Zimmer that Hector Mann, assumed to have been long dead, is still alive; what is more, he wants to meet Zimmer and invites him to his ranch. Before Zimmer embarks on the trip, the Southwest reaches out to him through its emissary, a woman named Alma Grund. Alma has been sent from Tierra del Sueño with a mission - she is to bring Zimmer to Hector's ranch without delay. The arrival of Alma in Vermont coincides with the onslaught of a storm, and the elemental fury of the tempest may be an external indication of Zimmer's fierce resistance to the prospect of recovery and his initial blunt refusal. But the decision to go with her to New Mexico, "sudden and altogether unexpected," was in his own reckoning the beginning of the story he is "trying to tell now." This reversal, prompted by his sympathy for Alma and the developing affection, sets the narrative wheels in motion.

Quite curiously, after their arrival in New Mexico, as they drive "down a series of desert highways," Zimmer is so engrossed with Alma's narration, so "caught up with Hector's story," that he barely notices the surroundings. He does not remember the details of the trip: "the only thing that comes back to me is the sound of our voices [...] and the sweetness of the air rushing in on me through a crack in the window. But the land is invisible" (Auster Mlusions 201). The aesthetic dimension of Zimmer's encounter with the region is suppressed. Granted, the landscape is characterized by him as "some of the most impressive country in North America," but it has 
no effect on him, its famous sublime grandeur barely registers. He admits, however, that "Under normal circumstances, I would have gawked at the landscape, pointing to rock formations and dementedlooking cacti, asking the name of this mountain or that gnarled shrub" (Auster Mlusions 200). The scenery of New Mexico is captured in all its essential features but the description is minimal. The significance of the Southwest emerges from the role it plays in the narrative, the impact it has on the characters, not from its verbal elaboration, not from its copious textual presence. The Southwest is not presented as a place; it exists rather as blank space and a potentiality, in keeping with the distinction suggested by Yi-Fu Tuan in Space and Place (6). In a similar vein, González claims that the "deep essence" of this region "seems to lie in the naked landscape, the open spaces unaffected by human beings" ("Western Images" 14).

On his way to the ranch, Zimmer learns from Alma that Hector and his wife, Frieda Spelling, drove to New Mexico for their honeymoon and decided to stay and live there as a couple of reclusive artists. She tells him that "There were dozens of artists out there by then," but "Hector and Frieda lived in another part of the state" (Auster Illusions 203), keeping to themselves. In the first half of the $20^{\text {th }}$ century, the Southwest attracted many famous figures, artistic souls and spiritual seekers, most notably D. H. Lawrence and Georgia O'Keefe, with Taos emerging as its cultural capital. As John Murray explains,

For much of the twentieth century, from the age of Lawrence through the age of Abbey, Taos functioned as a kind of latter-day Florence in the American Southwest. The area attracted many of the best minds and talents of the era, including the world-class scientists, engineers, and program administrators at the nearby Los Alamos National Laboratory. (14)

Like the famous bohemians and literary men in the 1930s, Hector found there a congenial atmosphere. In his case this meant literally the dry desert air that was beneficial for his respiratory problems. He had lost a lung as a result of a gunshot wound and his convalescence was enormously slow.

On one level, the founding of the Blue Stone Ranch by Hector and his wife in the middle of vast desert expanses of the Southwest represents an attempt to turn space into a place, to invest it with meaning and value. More importantly, however, the history of its 
creation resembles the American myth of taming the wilderness. As Alma explains, they had to build everything from the ground, and the construction of the estate from scratch looks like the reenactment of the Puritan errand into the wilderness. The description of its original site as "blank and savage space" recalls the Puritan vision of the New World as the howling wilderness. Hector's project of planting treesmade possible thanks to the underground irrigation system installed by him-marks the creation of the Garden of Eden in this empty and barren land, which was one of the central premises of the American Dream. As Alma puts it, "Hector turned [the desert] into a little forest [...] for me it's one of the most beautiful places on earth" (Auster Illusions 204). It is worth pointing out the singular reversal in the process: in Nick's vision at the end of The Great Gatsby the trees had been cut down to make the fulfillment of the American Dream possible, while in The Book of Illusions they had been brought to the desert, turning it into a fertile garden. Thus, subtraction and deletion have been replaced by addition and enrichment.

The death of his little son put an end to the brief period of Hector's happiness. The destruction of the paradisiac condition, when projected against the larger history of the nation, may signify the failure of the Utopian promise, the fall from innocence and the disillusionment with the American Dream. After the death of Hector and Frieda's child spells the end of the paradise, the next stage in the history of the ranch involves turning the property into a small movie studio. The transformation of the Garden of Eden, of the Promised Land, into a dream factory, an alternative Hollywood, parallels a similar transition in the history of the USA. The film industry, burgeoning in the early decades of the twentieth century, busily set about fabricating illusions which were to hold sway over the hearts and minds of the general public, perhaps in order to compensate for the inefficacy and degradation of the original American Dream. As Hortense Powdermaker explains in her classic study Hollywood, The Dream Factory:

Movies began as an extension of the Coney Island type of entertainment. The men who started them -some still in control- were usually small entrepreneurs, some from the field of cheap entertainment, some from other small business. The artist was not even present. Later, when he arrived on the scene, he came as the employee of those men, who by this time were big business and who still remain firmly in control. (28) 
In Auster's novel, the cover story justifying the secrecy of the whole venture features an eccentric Mexican millionaire, who allegedly "has built his own studio in the American wilderness" (Auster Ilusions 213). And this very phrasing emphasizes the recasting of New Mexico as the mythic unspoiled wild terrain encountered by the early English and Dutch settlers. However, Hector's secret film studio is a Hollywood with a difference. This version of Hollywood, kept secret from the world, is not bound by the rules of decorum, by standard conventions of taste and propriety. By making films just for himself and the few initiated Hector gains freedom as an artist. But Jonathan Boulter views this particular circumstance in negative terms, claiming that the films "would have an a priori spectrality, would, in fact, perhaps not function as films in any real, philosophical sense" (27). Furthermore, what Boulter calls "Mann's secret archive," in other words his film-making enterprise, is "marked by the absence of the very thing that motivates it: an audience, a witness" (28). It is worth noting that it is primarily in this capacity, as an audience, a witness, an expert on Hector Mann's silent comedies, that Zimmer is summoned to the ranch.

Thanks to his absolute freedom of expression, Hector may show on the screen "naked bodies," "down-to-earth sex," but also "childbirth," "urination," "defecation," all "a natural part of life." As Alma explains, he could let the camera "go on rolling for as long as he liked," he could show directly "carnal passion, the fulfillment of lust." This small studio secretly snugged away in the vast of expanses of the Southwest allows the unrestrained exploration of the totality of human experience. On a different note, Hector's private Hollywood with a difference is envisioned as an alternative to the capitalist society, reflecting the spirit of collectivism arising in the aftermath of the Great Depression. It turns out to be at heart a Utopian enterprise, an experiment in communal living and working in the vein of the famous Brook Farm in the nineteenth century. This fictional anti-capitalist enterprise has perhaps been modelled on the actual example, for as Murray notes,

Lawrence composed his Studies in American Literature (1923) during the Taos period, when he lived in a creative community that included the Taos Society, a group of artists that flourished between 1912 and 1927. Lawrence considered creating an alternative community -a 
western version of social experiments like Brooks Farm- while living on a ranch near Questa. (13-14)

In The Book of Mlusions, Alma points out that in Hector's private studio "No one did just one thing there. They were all involved, and they all put in incredibly long hours" (Auster Ilusions 211). Hector wrote, directed, and edited the films, Alma's father, Charles Grund, "lit them and shot them, and after the shooting was done, he and [her] mother did all the lab work" (Auster Ilusions 210). They "processed the footage, cut the negatives, mixed the sound, and saw everything through until the final prints were in the can" (Auster Ilusions 210). Alma's mother "performed in every film they made after that, mostly as the female lead, but she helped out on other fronts as well" (Auster Mlusions 210): sewing costumes, painting scenery, advising Hector on his scripts, working in the lab. Frieda was "in charge of sets and costumes," but she was also Hector's assistant editor," a "script supervisor, boom operator, focus puller whatever needed doing on that day, at that moment" (Auster Mlusions 210).

Alma declares that everything she is comes from the ranch, from Tierra del Sueño, which suggests the identity of Alma and the estate. Hector's statement that "Alma is the child of this place" reinforces her identification with Tierra del Sueño and with the Southwest as such. It is explained that her first name, Alma, is the feminine form of almus, meaning "nourishing, bountiful." So Alma Grund literally means "nourishing ground," "bountiful earth." This, in turn, qualifies New Mexico and determines its restorative, redemptive powers. Both Alma herself and the visit to Tierra del Sueňo nurture Zimmer's soul, heal his wounded psyche.

But Alma has a birthmark on the left side of her face, a "purple stain about the size of a man's fist, long enough and broad enough to resemble the map of some imaginary country" (Auster Illusions 100). It is her essence, her distinguishing characteristic, the determinant of Alma's identity. But the description of the birthmark discloses also the function assigned to her in the novel. She is the human counterpart of Land of Dream, the embodiment of New Mexico. Her face looks different, depending from which side it is viewed, which points to the contradiction in her person, the duality that perhaps reflects the ambivalence inherent in the Southwest. The region has served as a refuge for mavericks and artist fleeing from the commercialized modern society, seeking contact with the pristine 
wild nature of the Southwest. It also boasts a rich history, with preserved material artefacts, thus, giving rise to the unique sense of "a deep time" and antiquity. This complex, multilayered past is encapsulated by Zimmer in the catalogue of absences, when musing on the erasure of the Southwest's material heritage in the photographs of its plants in the book Weeds of the West: "No more ancient cliff dwellers, no more archaeological ruins, no more Spanish conquerors, no more Jesuit priests, no more Pat Garrett and Billy the Kid, no more Indian pueblos, no more builders of the atomic bomb" (Auster Illusions 295). What he fails to mention, however, is the Roswell incident, which triggered the subsequent massive UFO sightings, the most recent phenomenon testifying to the mythcreating potential of New Mexico and its contribution to the national imaginary. Nevertheless, for all its mystique and stark, captivating beauty, the Southwest has its darker underside: the harshness of the conditions that make this land "of prickly, water-starved vegetation" almost hostile to life, the bloody past that goes back to the Mexican War and its brutal conquest, and in the modern era, the location of a nuclear weapons development facility in Los Alamos.

Significantly, Alma's exposure of the left side of her face, the one with the birthmark, which she unwittingly turns to Zimmer, instead of the usual right one, is correlated with her remark about Frieda Spelling, Hector's wife: "I'm so pissed off, I could punch her in the face" (Auster Illusions 281). The demonstration of the ugly side of Alma's face and the threat of aggression foreshadow her violent outbreak, her accidental killing of Hector's widow. This may also point to the contradiction inherent in the region that Alma embodies in the novel: the stunning surface beauty of the Southwest and its destructiveness lurking just beneath.

After his return home Zimmer notices the stark contrast between New Mexico and Vermont; the latter appears to him "closed in itself, dark, clammy," a far cry from the purity of light in the Southwest, the glory of a desert sunset, at one point described by Zimmer as "an inundation of glowing golds and purples" (Auster Illusions 287). Vermont's lushness and greenness seem "unnatural" and "impossible." This reaction reveals that he has been thoroughly transformed by his brief exposure to the wide and barren expanses of New Mexico, its dryness, its fierce sunlight. Zimmer calculates the amount of time he has spent with Alma, only eight days altogether, but the result of this experience is incommensurate with its temporal span: "In eight short days, she had brought [him] back from the 
dead" (Auster Illusions 316). The effect of New Mexico on Zimmer brings to mind the result of D. H. Lawrence's encounter with the region, who in his essay titled simply "New Mexico" confessed: "I think New Mexico was the greatest experience from the outside world that I have ever had. It certainly changed me for ever" (30).

In a final analysis, The Book of Illusions and Travels in the Scriptorium offer highly divergent visions of the Southwest. In the latter, the Alien Territories, representing the American Southwest in the historical expansion of the United States, figure as a site of vicious struggle. Brutally invaded on a false pretext, they are unreservedly sacrificed to the interests of the Confederation, a quasityrannical political entity with imperialist ambitions. Auster's novel heavily revises the formative grand narratives of the American state. It dismantles the myth of the West, wherein the inexorable push to the West has been touted as the cradle of the American character and the proving ground of democracy, because it reveals the westward expansion as the acquisition of land by hook and by crook, the process that hinged on the displacement and elimination of the Native Americans, who could not be adapted to the needs of the growing American state. Denton-Borhaug poignantly emphasizes that their eradication, called "the genocide of First Peoples" and one of "the original sins" of the American state, cannot be easily integrated into the national imaginary and reconciled with the values upon which the nation is said to be founded (32). As Cornel West quoted by Denton-Borhaug observes, "We're grounded on the dispossession of land of our precious indigenous brothers and sisters and the violation of their bodies" (West quoted in Denton-Borhaug 32). Moreover, the conversion of the Alien Territories into an arena of massive slaughter, the desacralization of the wilderness unmasks the ugly underside of the original Puritan venture -the taming of the pristine natural world and the creation of a model Christian state for the rest of the world to admire.

By contrast, the Southwest in The Book of Illusions emerges as the site of the reenactment of the American Dream. The creation of the Blue Stone Ranch in the "wilderness" of New Mexico and its transformation encapsulate the history of the American nation in its essential stages: the fall from the original pre-lapsarian condition and its aftermath, the sway of fabricated illusions over American minds. But the duality of the region is explored, too, the harshness of the land coupled with its breathtaking surface beauty, its potential for violence alongside its curative power. In the novel, the Southwest, 
true to the appellation of its human counterpart Alma Grund, indeed proves to be "a nourishing ground." The novel may be aptly described as the story of trauma. And the recovery from trauma is a process that either originates or takes place in New Mexico.

By endowing the region with restorative and very nearly utopian properties, Auster's novel subscribes to the notion of "the 'strange mystic unknown' Southwest" (Murray 15), whose most vocal exponent in the contemporary era has been Edward Abbey. As Murray reports,

Abbey later wrote that "Of all the western states I love New Mexico best. [...] Brightest New Mexico, fairest of them all." He resided in northern New Mexico for five years, during his earliest and most formative period in the Southwest. (15)

But the origins of the mystique of the Southwest can be traced even further back, to D. H. Lawrence's essays on New Mexico written in 1920s. In addition to extolling its beauty, the English writer praises there the culture of the region for cultivating its connection with "a vast old religion which once swayed the earth," "a living tradition going back far beyond the birth of Christ, beyond the pyramids, beyond Moses" (Lawrence 33). In a prophetic pronouncement, Lawrence pits the permanence of the original culture of the Southwest, its authenticity, against the shallowness and fragility of the modern American state: "The sky-scraper will scatter on the winds like thistledown, and the genuine America, the America of New Mexico, will start on its course again" (Lawrence 36).

In the light of the above considerations, it cannot be denied that the examined novels of Paul Auster truly represent a new intervention in the national imaginary, notwithstanding the fact that each pursues its specific agenda and strategy. Travels in the Scriptorium aims primarily to expose the myth of the West and works to undermine its anesthetic influence on American minds, the influence that manifests itself in the willful oblivion of the destruction of the wilderness and the elimination of its aboriginal inhabitants. Quite relevantly, Denton-Borhaug draws attention to the fact that the national imaginary operates also by suppressing, by relegating shameful historical events to the "national subconscious":

But not only is the national imaginary replete with "non-rational" attempts to justify, explain away or repress this history, Renan also 
reminds us, “... forgetting ... is a crucial factor in the creation of a nation ... the essence of a nation is that all individuals have many things in common, and also that they have forgotten many things." (32)

On the other hand, The Book of Ilusions strives to refresh the American Dream by relocating it to the Southwest. By transplanting it to this particular region of the USA, Auster's novel subscribes to the larger cultural trend that is conveniently labeled "the mystique of the Southwest." This trend, growing in strength and appeal throughout the twentieth and twenty-first century, has offered an exciting alternative to the commercialized mainstream American society, and brought forth a surprising number of great artistic and literary works, all resulting from the encounter with this enchanting land.

\section{WORKS CITED}

AUSTER, Paul. The Book of Illusions. Faber \& Faber, 2003.

---. Day/Night. Two Novels: Travels in the Scriptorium and The Man in the Dark. Picador, 2013.

BOULTER, Jonathan. Melancholy and the Archive: Trauma, Memory, and History in the Contemporary Novel. Continuum International Publishing Group, 2011.

DENTON-BORHAUG, Kelly. "Is this America? Unfinished business with the U.S. national imaginary, religion and violence.” Dialog, 2019, Vol. 58, pp. 30-38.

DUNAWAY, David King, and Sara Spurgeon. "Introduction." Writing the Southwest Revised Edition, edited by D. King Dunaway and S. L. Spurgeon, University of New Mexico Press, 2003, pp. xxii-xlv.

FITZGERALD, Scott Francis. The Great Gatsby, Scribner, 2004.

FRIEDMAN, Susan Stanford. "Spatial Poetics and Arundhati Roy's The God of Small Things." A Companion to Narrative Theory, edited by James Phelan and Peter Rabinowitz, Blackwell, 2005, pp. 192-205.

GONZÁLEZ, Jesús Ángel. “'Another History’: Alternative Americas in Paul Auster's Fiction." Comparative American Studies, Vol. 9, No. 1, 2011, pp. 21-34. 
A New Intervention in the National Imaginary:

The Portrayal of the Southwest in the Novels of Paul Auster

---. "Western Images in Paul Auster's Work: from Moon Palace to Later Fiction." Beyond the Myth: New Perspectives on Western Texts, edited by D. Rio, A. Ibarraran, and M. Simonson, Portal Education, 2011.

LAWRENCE, David Herbert, "New Mexico." The Spell of New Mexico, edited by Tony Hillerman, University of New Mexico Press, 1984, pp. 29-37.

LOTMAN, Jurij, The Structure of The Artistic Text. Translated by Gail Lenhoff and Ronald Vroon, The University of Michigan, 1977.

LÖVE, Katharina Hansen, The Evolution of Space in Russian Literature. A Spatial Reading of 19-th and 20-th Century Narrative Literature, Rodopi, 1994.

MURDOCH, David H. The American West: The Invention of a Myth. University of Nevada Press, 2001.

MURRAY, John A. "Introduction." Abbey in America: A Philosopher's Legacy in a New Century, edited by J. A. Murray. University of New Mexico Press, 2015, pp. 1-26.

OPIE, John, and Norbert Elliot. "Tracking the Elusive Jeremiad: The Rhetorical Character of American Environmental Discourse." The Symbolic Earth: Discourse and Our Creation of the Environment, edited by J. G. Cantrill and C. L. Oravec, The University Press of Kentucky, 1996, pp. 9-38.

POWDERMAKER, Hortense. Hollywood, The Dream Factory -An Anthropologist Looks at the Movie-Makers. Little Brown and Company, 1950.

RYAN, Marie-Laure "Space." The Living Handbook of Narratology, edited by Peter Hühn et al., Hamburg: Hamburg University. Accessed 11 June 2014.

STRONG, Pauline Turner. American Indians and the American Imaginary: Cultural Representation Across Centuries Routledge, 2016.

STUDNIARZ, Sławomir. "The American Waste: A New Take on the Conquest of the West in Paul Auster's Novel Travels in the Scriptorium." ECOZON@Vol 9, No 2 (2018),pp. 89-105.

TUAN, Yi-Fu. Space and Place: The Perspective of Experience. University of Minnesota Press, 2001. 